cultural Organisation had to remain primarily as observers-much to the frustration of some who claimed considerable practical experience in the issues under discussion.

However, the plan of action makes a number of suggestions about how research should be conceived within the TCDC framework. For example, it speaks of the need for developing countries to combine research efforts and share results "both with one another and with other developing countries by means of agreements on scientific and technological co-operation, strengthening national design, national laboratories, research centres and scientific and other institutions".

Putting flesh on these ideals will be one of the main objectives of next year's United Nations Conference on Science and Technology for Develop- ment, which will take place in Vienna. But many delegates left Buenos Aires with the feeling that despite internal differences, the developing countries have found in the issue of technical co-operation a way in which they can work together in presenting concrete demands to the developed world, and that this in itself was a major step in bringing the new economic order closer to reality.

\title{
US geneticists look to Europe for research facilities
}

Researchers at Genentech Inc, San Francisco, claimed at a Munich conference last week that they have induced bacteria to synthesise the two separate amino acid chains of human insulin-and to have combined these chains to make minute quantities of the hormone. Last year, the same team used a similar technique to induce bacteria to produce the hormone, somatostatin, and earlier this year, another team led by Walter Gilbert of Harvard University announced that they had persuaded bacteria to produce rat proinsulin attached to the bacterial ensyme penicillinase.

Synthesis of the artificial insulin gene used by Genentech began at City of Hope Medical Centre, California late last year. Researchers there synthesised artificial genes consisting of the DNA sequence corresponding to the amino acid sequence of the $A$ and $B$ strands of human insulin. Six months later, they turned the synthetic genes over to David Goeddel and Dennis Kleid, biochemists at Genentech.

Goeddel and Kleid inserted the synthetic genes for the two strands of insulin into plasmids which were then introduced separately into Escherichia coli. The bacteria replicated and expressed the genes as the $\mathrm{A}$ and $\mathrm{B}$ amino acid chains. These were then mixed to produce a fraction of a milligram of insulin which, it is claimed, is similar to human insulin.

Biological tests for the activity of insulin, however, have yet to be done. Even though chemical tests and radioimmunoassay have indicated the presence of the molecule, some researchers question the claim that the insulin produced is the chemical equivalent of human insulin. This is because radioimmunoassay cannot distinguish between different insulin varieties. Also, the B-peptide chains produced during the recent work are impure, and some researchers feel that the amino acid analyses conducted so far may be insufficient to establish the presence of the desired sequence.

The development of a new source of insulin for the treatment of diabetes has great practical importance. About $5 \%$ of diabetics are allergic to the animal insulin now used, and each patient requires 10 bovine pancreases per year at a cost of more than $\$ 100$. Bacterially produced insulin should eliminate allergic reactions and may be cheaper and easier to supply than animal insulin. Before the newly produced insulin could be marketed, however, it would have to undergo extensive animal and human tests which could take two to five years, though Genentech president Robert Swanson foresees no real difficulties in scaling up the procedure and passing the tests.

Such rapid success in developing a practical application of a technique raises a host of questions. The technique was discovered so recently that the original patent application has not yet been processed, and neither have revised safety regulations been implemented. Already the race for other commercial applications is hotly contested. New patents have been applied for, the breadth of the original patent remains unclear, and several leading American researchers are reportedly setting up shop in Europe to escape regulatory delays.

The original research leading to the procedure used in synthesising artificial genes was conducted with funds from the National Cancer Institute, the

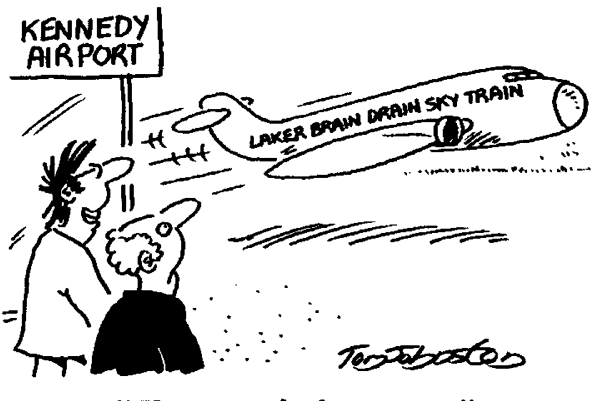

"Yes, we go both ways now"
National Science Foundation, the National Institutes of Health, the University of California and Stanford University. All parties eventually agreed that NIH would enter an institutional patent agreement with Stanford University and the University of California. Stanford would administer licensing of the technology, under terms of the agreement and share royalties equally with the University of California. After public hearings last spring, NIH granted Stanford permission to go ahead with licensing, provided any company granted a license would abide by NIH safety guidelines for genetic engineering.

Niels Reimers, Stanford's manager of technology licensing says he expects a patent to be issued within a matter of months, and believes it will cover much of the basic technique for producing recombinant DNA in $E$. coli. Stanford will probably wait until the patent is actually issued to begin licensing.

Such a patent would apply only in the United States. For that reason, and because of early stringent regulations, some scientists who are trying to create insulin by isolating and transferring a human gene have gone to Europe to work. Applications to use the country's first super-secure "P-4" facility, at Fort Dietrick, Maryland, will not be processed until later in the autumn. New, less stringent safety guidelines will also not go into effect until later this year.

William Rutter, a molecular biologist at the University of California, San Francisco, is already looking to Europe as the place to continue his work on the human gene for insulin. "One is forced to do that if one wants to do the experiments" he says. His group is planning to work in France. The potential advantage of using the natural gene for insulin, he says, is that it includes additional information for folding and joining the $A$ and $B$ peptide strands.

John Douglas 